\title{
Splenic Artery
}

National Cancer Institute

\section{Source}

National Cancer Institute. Splenic Artery. NCI Thesaurus. Code C33597.

An artery arising from the celiac trunk with four main branches that supply the spleen, stomach and pancreas. 